\title{
Effective bioreduction of hexavalent chromium-contaminated water in fixed-film bioreactors
}

\author{
Peter J Williams', Elsabe Botes', Maleke M Maleke', Abidemi Ojo', Mary F DeFlaun², Jim Howell², \\ Robert Borch ${ }^{2}$, Robert Jordan ${ }^{1}$ and Esta van Heerden ${ }^{1 *}$ \\ ${ }^{1}$ TIA Metagenomics Platform, Department of Microbial, Biochemical and Food Biotechnology, University of the Free State, South Africa \\ ${ }^{2}$ Geosyntec Consultants, Ewing, New Jersey, USA
}

\begin{abstract}
Hexavalent chromium $\left(\mathrm{Cr}^{6+}\right)$ contamination from a dolomite stone mine in Limpopo Province, South Africa, has resulted in extensive groundwater contamination. In order to circumvent any further negative environmental impact at this site, an effective and sustainable treatment strategy for the removal of up to $6.49 \mathrm{mg} / \ell \mathrm{Cr}^{6+}$ from the groundwater was developed. Laboratory-scale, continuous up-flow bioreactors were constructed to evaluate reduction of $\mathrm{Cr}^{6+}$, with a residence time of $24 \mathrm{~h}$, an efficiency porosity of $44 \%$ and a flow rate of $1.5 \mathrm{~m} / / \mathrm{min}$. Stoichiometrically balancing terminal electron acceptors in the feed water with a selected electron donor, directed reactor balance for complete $\mathrm{Cr}^{6+}$ reduction. The microbial community shifted in relative dominance during operation to establish an optimal metal-reducing community, including Enterobacter cloacae, Flavobacterium sp. and Ralstonia sp., which achieved 100\% reduction. Evaluation after reactor termination with SEM-EDX and XRD confirmed the establishment of biofilm on the reactor matrix, as well as trivalent chromium $\left(\mathrm{Cr}^{3+}\right)$ precipitation within the reactor. Due to gravitational force, high concentrations of $\mathrm{Cr}^{3+}$ were found in the bottom third of the reactor. Based on the results from the laboratory investigation, a $24000 \mathrm{l}$ fixed-film pilot bioreactor was designed and constructed at this site. Influent flow rates, electron donor injection and automated sampling were remotely controlled by a programmable logic controller (PLC). Similar to the laboratory column study, steady state conditions could be achieved and successful $\mathrm{Cr}^{6+}$ reduction was evident. This is the first up-scaled, effective demonstration of a biological chromium(VI) bioremediation system in South Africa.
\end{abstract}

Keywords: Bioreduction, fixed-film reactor, hexavalent chromium, microbial diversity

\section{INTRODUCTION}

The study source site is located in the Limpopo Province of South Africa at a facility that actively mines and processes marble and dolomite stone as a graded aggregate for landscaping and construction purposes. Unrelated historic land-use activities resulted in ground and surface water contamination with hexavalent chromium $\left(\mathrm{Cr}^{6+}\right)$. Despite efforts to prevent migration of site wastes to the surrounding environment, leaching of $\mathrm{Cr}^{6+}$ into the groundwater has occurred over the 80-year history of the site. Over a 5 -year sampling period, measured $\mathrm{Cr}^{6+}$ concentrations in site groundwater ranged between 2.30 and $6.49 \mathrm{mg} / \ell$.

Hexavalent chromium is classified as a SABS 0228 danger group 8(II) compound leading to birth defects and reproductive impairment (Arlauskas et al. 1985; DWAF, 1998; Kanojia et al., 1998). It can cross the cellular membrane via sulphate transporters and, once inside the cell, can generate reactive oxygen species (ROS), implicated as mutagens and carcinogens, from the cyclic single electron transfer between $\mathrm{Cr}^{6+}$, molecular oxygen and $\mathrm{Cr}^{5+}$ (Ackerley et al., 2004). Trivalent chromium, on the other hand, is considered to be relatively innocuous and usually occurs as insoluble organic and inorganic complexes due to its strong Lewis acid nature (Barceloux, 1999).

The preferred technology for treatment of $\mathrm{Cr}^{6+}$ in South Africa is chemical reduction with ferrous sulphate or sodium

To whom all correspondence should be addressed.

5 +27 51401 2472; e-mail: vheerde@ufs.ac.za

Received 24 October 2013; accepted in revised form 25 June 2014. sulphite, followed by co-disposal and landfilling of residues (DWAF, 1998). However, chemical treatment of $\mathrm{Cr}^{6+}$ requires high concentrations of reagents, generates environmentally hazardous by-products and is generally more effective at higher concentrations (Szpyrkowicz et al., 2001). The potential for application of bioreduction of $\mathrm{Cr}^{6+}$ as an alternative remediation strategy has been highlighted in several publications; however, this is the first attempt at a systematic study aimed at an industrial-scale bioreactor with larger volumes (Thacker et al., 2006; Amoosegar et al., 2007).

Biological reduction of $\mathrm{Cr}^{6+}$ with indigenous bacteria in semi-passive systems can be an environmentally sound alternative or complementary technology to active chemical treatment technologies, but at comparatively lower lifecycle costs with less specialised labour requirements. Bacterial reduction of $\mathrm{Cr}^{6+}$ to its less toxic form is a complex phenomenon and can proceed under both aerobic and anaerobic conditions utilising membrane or cytoplasmic proteins that may or may not require the presence of co-factors (Opperman and Van Heerden, 2007). Dissimilatory chromate-reducing bacteria utilise $\mathrm{Cr}^{6+}$ as terminal electron acceptor, ultimately precipitating it as insoluble chromium hydroxides, demonstrating the potential for remediation (Desai et al., 2008).

A fixed-film bioreactor is a treatment process which employs a porous media with an attached biofilm through which contaminated water is passed and treated. The main functions of the media are to provide attachment sites for the biofilm, a hydraulic network for conveying flow through the system as well as minerals for biofilm development. The biofilm helps to create a physical environment within the bioreactor 
which encourages chemical transformation of certain soluble pollutants. Insoluble particulates are readily adsorbed to the biofilm surface and sequestered in the biomass. Similarly, Orandi et al. (2012) demonstrated the removal of a number of pollutants from acid mine drainage contaminated water using algal-microbial biofilm.

The environmental condition within the bioreactor that is of most interest for metals treatment in natural waters is the redox potential (ORP/Eh). For $\mathrm{Cr}^{6+}$ treatment, the microbes in the reactor are used to drive the environment to a reducing state while maintaining a relatively neutral $\mathrm{pH}$. At the desired redox potential $(\approx-200 \mathrm{mV})$ and with the preferred consortium dominating the biofilm, desirable physical and chemical reactions can occur. In the present study, this is achieved by introducing the inoculum to the media matrix, carefully regulating their metabolic activity by controlling the available carbon source and stoichiometric balancing with the electron acceptors as well as controlling the hydraulic retention time.

\section{MATERIALS AND METHODS}

\section{Source water and electron donor}

Source water was collected in batches from the site, transported to the laboratory and stored at $4^{\circ} \mathrm{C}$ in $25 \ell$ carboys. Each batch was analysed for key chemical constituents at the Institute for Groundwater Studies, University of the Free State. Food-grade citric acid was used as an electron donor that is readily available. The citric acid was analysed for the presence of impurities or inhibitory substances by HPLC on an Aminex $87 \mathrm{H}$ column at $60^{\circ} \mathrm{C}$ using $0.01 \mathrm{~N} \mathrm{H}_{2} \mathrm{SO}_{4}$ at $0.6 \mathrm{ml} / \mathrm{min}$ as mobile phase (Schneider et al., 1987).

\section{Up-flow column set-up and operation}

The bioreactor was constructed from $110 \mathrm{~mm}$ polyvinyl chloride (PVC) pipe with threaded end caps, taps and appropriate silicon tubing. The bioreactor was packed with dolomite stone to infer uniformly-graded and packed material, with selected hydraulic properties. The media bed was hydrated with water and the reactor drainage volume determined. The pore volume (PV), static- (Eq. (1)) and efficiency porosity (Eq. (2)) was determined by performing a tracer test with $5 \mathrm{mM} \mathrm{NaCl}$.

Static porosity $=$ drainage volume/empty bed volume

Efficiency porosity $=$ tracer peak volume/empty bed volume

The bioreactor was seeded with a $5 \%(\mathrm{v} / \mathrm{v})$ solution of biome collected from a groundwater seep at the site that contained a metabolically diverse consortium of bacteria able to reduce a range of substances, including $\mathrm{NO}_{3}^{-}, \mathrm{Fe}^{3+}, \mathrm{Cr}^{6+}$ and $\mathrm{SO}_{4}^{2-}$. Influent water, containing $500 \mathrm{mg} / \ell$ citric acid adjusted to $\mathrm{pH} 6$ with $1 \mathrm{M} \mathrm{NaOH}$, was introduced to the base of the bioreactor using a Watson Marlow Bredel S520 peristaltic pump at a 24-h hydraulic retention time (HRT). Effluent water was characterised during the operation of the bioreactor, while the redox potential (ORP/Eh), $\mathrm{pH}$, electrical conductivity (EC), temperature (HI $9828 \mathrm{pH} / \mathrm{ORP} /$ EC/DO probe, Hanna Instruments Inc, Woonsocket, RI, USA), bacterial cell counts (Porter and Feig, 1980) and $\mathrm{Cr}^{6+}$ concentrations (Urone, 1955) were monitored. Once reducing conditions were established within the bioreactor, the electron donor was incrementally lowered until the minimum donor requirement was determined empirically.

\section{Bioreactor termination}

After continuous operation for 6 months (representing approximately $775 \ell$ of contaminated water having flowed through the reactor), the bioreactor was drained in timed $500 \mathrm{~m} \ell$ increments and each drained fraction recorded to correspond with a specific section of the column. The bioreactor was cut open lengthwise and matrix samples collected for microscopic examination, including scanning electron microscopy (SEM), X-ray fluorescence- and energy dispersive X-ray spectroscopy analyses.

\section{Microbial diversity}

Microbial diversity shifts were studied during the bioreactor operation with daily sample $(1 \mathrm{~m} \ell)$ collection. Samples were analysed corresponding to selected redox potential and electron donor concentration changes during the operation of the column bioreactor. The centrifuged cell pellets from each sample were re-suspended in $50 \mu \ell \mathrm{ddH}_{2} \mathrm{O}$ and used as a template for amplification of a $\approx 200 \mathrm{bp}$ fragment of the $16 \mathrm{~S}$ rDNA with universal bacterial primers 341F-GC (Muyzer et al., 1993) and 517R (Reysenbach et al., 1992), to analyse shifts in the microbial community. Amplification products were separated on an $8 \%(w / v)$ polyacrylamide gel with a urea/formamide denaturing gradient ranging from $30 \%$ to $60 \%$. Electrophoresis was performed in $1 \mathrm{X}$ TAE buffer, $\mathrm{pH} 8.0$ at a constant voltage of $200 \mathrm{~V}$ at $60^{\circ} \mathrm{C}$ for $3 \mathrm{~h}$. Gels were stained with SYBR Gold (0.05\%) (Life Technologies, Carlsbad, CA, USA) and viewed with a UV transilluminator (Bio-Rad Laboratories, Hercules, CA, USA).

The terminated bioreactor community was analysed by filtering the water samples corresponding to the different fractions through $0.22 \mu \mathrm{m}$ polyethersulfone (PES) membrane filters. Genomic DNA was extracted using the NucleoSpin soil kit (Macherey-Nagel, Düren, Germany), following the manufacturer's instructions. Partial 16S rDNA fragments $(\approx 600 \mathrm{bp})$ were amplified from the gDNA extracts using universal bacterial primers 341F-GC and 907RM (Muyzer et al., 1993), resulting in larger DNA fragments for identification of the bacteria present in the microbial community. The amplification products were separated on a $7 \%(\mathrm{w} / \mathrm{v})$ polyacrylamide gel as described above. Predominant bands were excised and re-amplified using the primers 341F and 907RM (Muyzer et al., 1993). The amplification products were purified using the Biospin Gel Extraction kit (Bio Flux Corporation, Tokyo, Japan). Sequencing of the rDNA fragments was performed using the ABI BigDye Terminator v3.1 Ready Reaction Sequencing kit (Life Technologies, Carlsbad, CA, USA). The sequences were submitted to the National Center for Biotechnology Information (NCBI).

\section{Construction and operation of a pilot fixed-film bioreactor}

Following the laboratory up-flow column bioreactor study, a pilot-scale treatment system was designed, constructed, operated and monitored to evaluate this technology for inclusion in the overall site remediation programme. The proposed treatment approach is similar to an in-situ bioremedial system developed by Geosyntec Consultants, USA. A concrete containment structure of $15.2 \mathrm{~m} \times 4.28 \mathrm{~m} \times 0.85 \mathrm{~m}$ was constructed at a $\mathrm{Cr}^{6+}$ contaminated site. The containment structure was lined with a heavy-duty polyvinyl liner installed between two layers of geotextile material. Thereafter, the containment structure was filled with dolomite stone resulting in a media porosity of $44 \%$. Sampling ports (5) were imbedded in the reactor matrix media 


\begin{tabular}{|l|l|c|c|}
\hline \multicolumn{4}{|c|}{ TABLE 1 } \\
\hline $\begin{array}{l}\text { Electron } \\
\text { acceptor }\end{array}$ & Balanced redox reaction & $\begin{array}{c}\text { Concentration } \\
(\mathbf{m g} / \ell)\end{array}$ & $\begin{array}{c}\text { Donor demand } \\
(\mathbf{m g} / \ell)\end{array}$ \\
\hline Oxygen & $2 \mathrm{C}_{6} \mathrm{H}_{8} \mathrm{O}_{7}+9 \mathrm{O}_{2} \rightarrow 8 \mathrm{H}_{2} \mathrm{O}+12 \mathrm{CO}_{2}$ & 8.00 & 10.67 \\
\hline Nitrate & $5 \mathrm{C}_{6} \mathrm{H}_{8} \mathrm{O}_{7}+18 \mathrm{NO}_{3}+18 \mathrm{H}^{+} \rightarrow 29 \mathrm{H}_{2} \mathrm{O}+30 \mathrm{CO}_{2}+9 \mathrm{~N}_{2}$ & $60.75 \pm 7.80$ & $52.29 \pm 6.72$ \\
\hline Chromate & $\mathrm{C}_{6} \mathrm{H}_{8} \mathrm{O}_{7}+6 \mathrm{CrO}_{3}+5 \mathrm{H}_{2} \mathrm{O} \rightarrow 6 \mathrm{Cr}(\mathrm{OH})_{3}+6 \mathrm{CO}_{2}$ & $5.97 \pm 0.52$ & $7.65 \pm 0.67$ \\
\hline Sulphur & $4 \mathrm{C}_{6} \mathrm{H}_{8} \mathrm{O}_{7}+9 \mathrm{SO}_{4}^{-}+18 \mathrm{H}^{+} \rightarrow 16 \mathrm{H}_{2} \mathrm{O}+24 \mathrm{CO}_{2}+9 \mathrm{H}_{2} \mathrm{~S}$ & 15.00 & 13.33 \\
\hline Total & & & $83.94 \pm 7.39$ \\
\hline
\end{tabular}

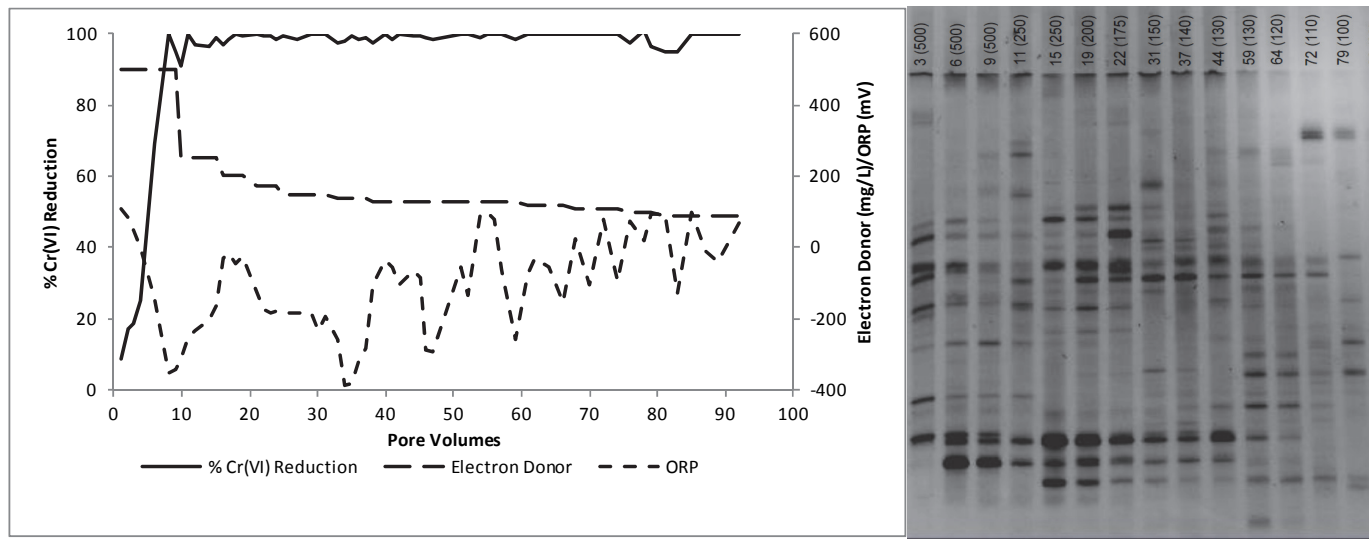

Figure 1

A: Start-up and operation of the $\mathrm{Cr}^{6+}$ reducing bioreactor; B: Denaturing gradient gel electrophoresis (DGGE) of selected pore volumes during the electron donor weaning period. (Pore volumes are indicated numerically, while electron donor concentrations (in $\mathrm{mg} / \mathrm{l}$ ) are bracketed).

for manual as well as automated sampling and parameter monitoring. A PVC influent manifold system was installed (a third of the reactor height) at the front end of the reactor to distribute the influent water uniformly across the vertical cross-section of the reactor matrix. A PVC discharge manifold was installed in the back-end of the reactor at half the height of the reactor wall, running across the width of the reactor. The effluent was collected into a sump that leads to an aeration cascade.

As in the case of the laboratory column bioreactors, citric acid was used as the electron donor and a stock solution was prepared in a $500 \mathrm{\ell}$ holding tank from where it was injected into the influent line via a dosing pump (Grundfos DDI 209, Grundfos Holdings A/S, Bjerringbro, Denmark) controlled by a programmable logic controller (PLC); (Siemens AG, Munich, Germany).

The reactor source water was relayed from an elevated cement distribution dam through gravitational feed providing $167 \mathrm{kPa}$ of static pressure, which is sufficient for a constant source water flow rate to the reactor. An electronic flow control valve (Type 3003, Bürkert Fluid Control Systems, Ingelfingen, Germany) with a flow rate meter (Type 8032, Bürkert Fluid Control Systems) was installed in the influent line to regulate the influent water flow into the reactor.

The bioreactor was monitored by an automated PLC system consisting of a sampling pump (TeknaEvo 500, Seko Spa, Rieti, Italy) and valved manifold feeding into a redox potential sensor (Orbisint CPS12, Endress + Hauser, Reinach, Switzerland) connected to a controller box (Liquiline CM442, Endress + Hauser). Data on reactor water level and influent feed rate was collected continuously and redox potential measurements taken at 6-h intervals. Data was logged into a CSV file, backed up on the PLC itself and sent to the off-site operator via an internet connection.

\section{RESULTS AND DISCUSSION}

\section{Laboratory-scale bioreactor}

A bioreactor was packed with dolomite stone collected from the site to achieve a uniformly packed matrix of $43 \%$ and $44 \%$ staticand efficiency-porosity, respectively, as inferred from symmetrical conservative tracer curves and peak electrical conductivity measurements. High pressure liquid chromatography analysis of the citric acid purchased from the local vendor indicated that the compound was highly similar to analytical grade citric acid with regards to chromatographic retention time, purity and concentration. Chemical analysis of the source water demonstrated that during the course of a 2 -year sampling period, the water composition remained fairly uniform. The major terminal electron acceptors in addition to chromate were nitrate (60.75 \pm $7.80 \mathrm{mg} / \ell)$ and sulphate $(402.40 \pm 33.03 \mathrm{mg} / \ell)$, with low concentrations of other metals such as iron and manganese. By stoichiometrically balancing terminal electron acceptors present in the feed water with the potential electron donor, the theoretical amount of citric acid required for complete chromate bioreduction could be calculated (Table 1).

The bioreactor achieved $\approx 100 \%$ chromate reduction after 7 pore volumes $(\mathrm{PV})$; (expressed as a percentage of chromate in the influent feed solution) with redox potential readings indicating anoxic conditions within the bioreactor (Fig. 1). As the amount of electron donor in the influent water was gradually lowered, chromate reduction was maintained at $>95 \%$ (Fig. 1). The microbial community profiling by denaturing gradient gel electrophoresis (DGGE) during the period of electron donor weaning shows evidence of the biological activity in the bioreactor, as a highly adaptive bacterial community with shifts in 
dominance occurs (Fig. 1).

The bacterial community at PV 3 was diverse, showing various dominant bacterial species, as indicated by the band intensity; however, during this time there was $<20 \%$ chromate-reducing activity in the bioreactor, indicating that the community was able to tolerate the chromate, but was not efficient at reducing it to trivalent chromium. A shift in the bacterial community occurred from PV 6, coinciding with an increase in reduction potential and increase in chromate reduction $(\approx 70 \%)$, thereby providing crucial evidence of biological chromate reduction as all parameters were kept constant during this period. Adaptations in the microbial community composition continued as the electron donor concentration was gradually decreased, which also corresponded with the fluctuations in the redox potential. An example of this is PVs $11(-225 \mathrm{mV})$ and $15(-165 \mathrm{mV} /)$, both corresponding to an electron donor concentration of $250 \mathrm{mg} / \ell$ and $\approx 100 \%$ chromate reduction (Fig. 1). Pore volume 11 represents a snapshot of the microbial community shortly after lowering the electron donor concentration, while PV 15 represents the bacterial community adapted to this electron donor concentration. A similar adaptive trend can be seen with PVs 44 (-66 $\mathrm{mV}$ ) and 59 (-256 mV) (Fig. 1).

The minimum concentration of electron donor $(90 \mathrm{mg} / \mathrm{\ell})$ at these operational conditions $(24 \mathrm{~h}$ and hydraulic retention time; $\left.5.97 \pm 0.52 \mathrm{mg} / \ell\left[\mathrm{Cr}^{6+}\right]\right)$ corresponded well with the calculated electron donor demand of $83.94 \pm 7.39$ (Table 1). The small difference between the empirical- and calculated electron donor demand values can be attributed to the complex nature of the system, with many factors such as metabolic flux and contributions from other metals (iron and manganese) that were not taken into account during electron donor requirement calculations. In terms of the microbial community, operating the bioreactor at the lower limit of electron donor feed represents a stressed environment, which is reflected by the adaptations and changes in the bacterial community profile PVs 64, 72 and 79 (Fig. 1). The initial intention was the removal of the $\mathrm{Cr}^{6+}$ from the water; however, after treatment it was evident that the water complied with Class 2 drinking water (SANS, 2011). This is due to the reduction potential favouring specific metabolic activities; the reductant (citric acid) transfers electrons to the lowest unoccupied electron level, before transferring electrons to higher unoccupied electron levels, such as nitrate (Stumm and Morgan, 1996). If this balance favours excess electrons added to the system as a result of the stoichiometric balancing to include a portion of the available sulphate, electrons are transferred to all lower unoccupied electron levels, which include oxygen, nitrate, manganese, iron and chromate, resulting in their subsequent reduction. Thus, as an additional benefit, potential contaminants such as nitrates and sulphates are also removed from the water.

After bioreactor termination, a green precipitate was clearly visible in the bottom third of the bioreactor, which corresponds to increased levels of chromium as determined by XRF and EDX analyses (Fig. 2 and 3). Since this bioreactor was operated in upflow mode with the electron donor arrival at the bottom, the maximal nutrients would be at an inlet location near the bottom of the reactor. As a result, maximal activity in a form of a green precipitate was observed with the light microscopy.

During the operation of the bioreactor, there were no appreciable changes in the matrix porosity, indicating that operation of the bioreactor under these conditions did not present a significant clogging potential. Light microscopy of the matrix material showed discrete patches of biofilm with little potential for pore clogging, as would be the case if continuous slime films were present. Biofilm formation on the matrix surface was also clearly demonstrated by SEM imaging (Fig. 3), as shown by Marsili et al. (2007).

Microbial diversity analysis of the established stable community within the different fractions of the bioreactor showed a number of uncultured bacteria, which indicates the novelty in the biodiversity present in the water fractions from the chromium-reducing bioreactor (Table 2). In addition, various sequences were related to bacteria able to reduce a variety of elements and compounds, including (i) nitrate, such as Chloroflexi sp. (Kawaichi et al., 2013), Flavobacterium sp. (Park et al., 2006), Acidobacteria sp. (Ward et al., 2009), Ralstonia sp. (Coenye et al., 1999; Chen et al., 2001) and Enterobacter cloacae (Losi and

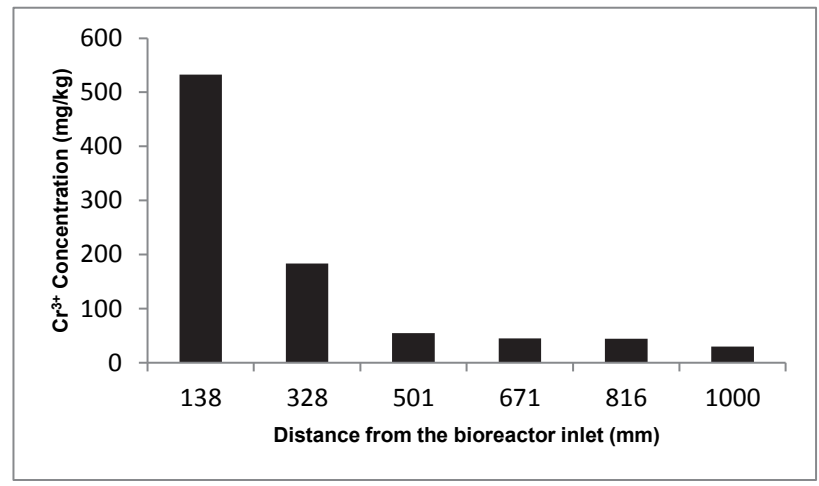

Figure 2

Precipitated chromium on the bioreactor matrix fractions after termination
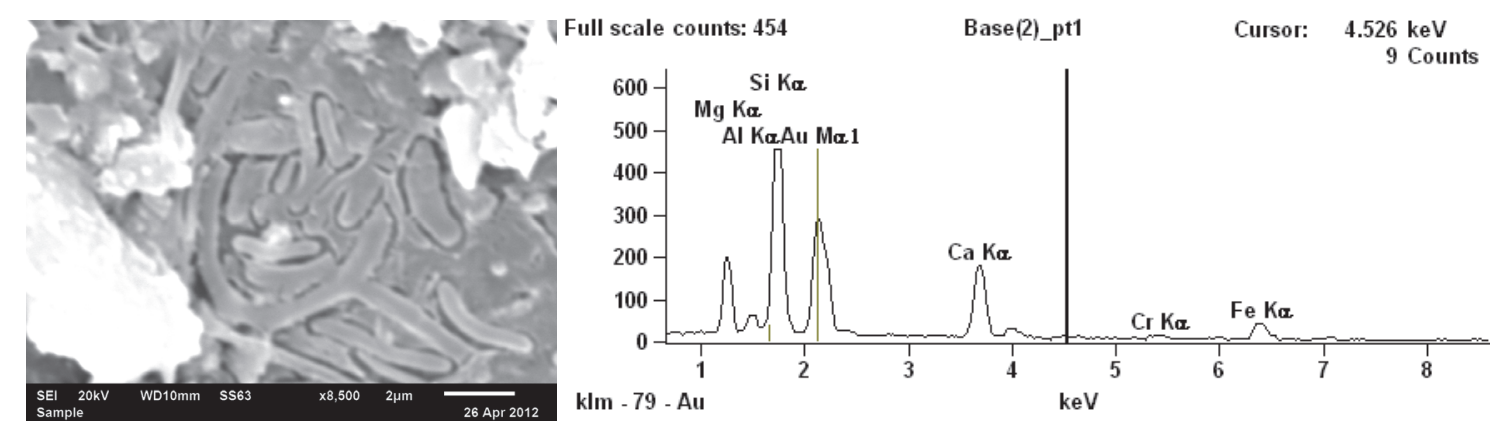

Figure 3

SEM and EDX analyses confirmed biofilm formation and chromium precipitation on the matrix surface 


\begin{tabular}{|l|l|c|}
\hline \multicolumn{2}{|c|}{ TABLE 2 } \\
\hline $\begin{array}{l}\text { Accession } \\
\text { number }\end{array}$ & BLASTN sequence alignment & $\begin{array}{c}\text { Maximum } \\
\text { identity }\end{array}$ \\
\hline JF508351.1 & Uncultured Chloroflexi bacterium clone AlertH04 16S ribosomal RNA gene, partial sequence & $98 \%$ \\
\hline HM062452.1 & $\begin{array}{l}\text { Uncultured Acidobacteria bacterium clone KBS_T1_R4_149264_b9 16S ribosomal RNA gene, partial } \\
\text { sequence }\end{array}$ & $99 \%$ \\
\hline KF453773.1 & Enterobacter cloacae strain JUNL-10 16S ribosomal RNA gene, partial sequence & $99 \%$ \\
\hline KC914541.1 & Ralstonia sp. CPO 4.0037 16S ribosomal RNA gene, partial sequence & $99 \%$ \\
\hline JX066803.1 & Flavobacterium sp. BX12 16S ribosomal RNA gene, partial sequence & $97 \%$ \\
\hline EF188662.1 & Uncultured alpha proteobacterium clone 2030 16S ribosomal RNA gene, partial sequence & $99 \%$ \\
\hline
\end{tabular}

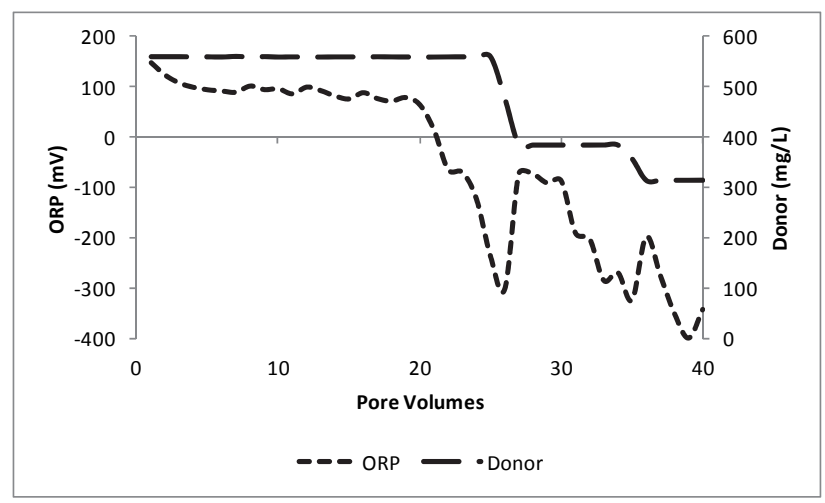

Figure 4

ORP and electron donor profiles during the first 40 pore volumes after bioreactor commissioning

Frankenberger, 1997); (ii) nitrite, such Flavobacterium sp. (Park et al., 2006), Acidobacteria sp. (Ward et al., 2009) and Ralstonia sp. (Coenye et al., 1999); (iii) iron(III), such as Chloroflexi sp. (Kawaichi et al., 2013) and Acidobacteria sp. (Blothe et al., 2008); (iv) chrome(VI), such as Enterobacter cloacae (Wang et al., 1989; Wang et al., 1990; Rege et al., 1997); (v) selenium oxyanions, such as Enterobacter cloacae (Watts et al., 2003; Losi and Frankenberger, 1997; Ridley et al., 2006; Yee et al., 2007) and Ralstonia sp. (Valls et al., 2000; Sarret et al., 2005); and (vi) arsenic, such as Flavobacterium sp. (Macur et al., 2004).

\section{On-site pilot bioreactor}

The $24000 \ell$ fixed-film pilot bioreactor was successfully operated at a hexavalent chromium-contaminated site. The redox potential and electron donor profiles during the first 40 days after bioreactor commissioning are illustrated in Fig. 4 . The bioreactor was started up using $550 \mathrm{mg} / \ell$ citric acid as electron donor to promote the formation of biofilm on the matrix of the bioreactor (Fig. 4). The redox potential within the reactor reached anoxic conditions after 22 PVs (Fig. 4), indicating the successful formation of the biofilm on the matrix of the reactor. The electron donor was gradually decreased during the following 18 PV's to $315 \mathrm{mg} / \ell$ (Fig. 4), resulting in a further decrease of the redox potential to $-400 \mathrm{mV}$.

After 22 PVs $>95 \%$ chromate reduction was achieved as a result of the anoxic conditions within the bioreactor, which indicates the biological activity responsible for the hexavalent chromium reduction. Similar to the laboratory column study, steady-state conditions could be achieved, resulting in maintaining the reduction of chromium(VI) (>99\%) and nitrate (>80\%) and therefore facilitating an added benefit by supplying water which could be used for sanitary purposes on site. This is the first up-scaled, effective demonstration of a start-up $\mathrm{Cr}^{6+}$ bioremediation system in South Africa.

\section{CONCLUSIONS}

The design of the up-flow bioreactor can be applied to a myriad of metal (and other) potential contaminants commonly found in aqueous environments by effective management of the redox potential and electron donor/acceptor balancing to direct bacterial biofilm development and steady-state activity. The presence of a suitably adapted microbial community effective for chromium reduction is essential for this system. Microbes are extremely adaptable due to their high cell turnover and corresponding high evolutionary rate, and the potential for horizontal gene transfer through plasmids and transposons, therefore, it is highly probable that an appropriate microbial community will be present in any historically contaminated environment. Given the potential for accessing the appropriate microbial community at sites where the indigenous bacterial community has been exposed and adapted to contamination, this system may be used as a model for other chromium-contaminated sites. This contaminant has been present for 80 years in this specific environment, allowing indigenous bacteria to adapt to the chromium and be used as effective biocatalysts for chromium reduction. During this project it became clear that scaling up from laboratory reactors to an on-site pilot reactor presented various challenges. The start-up of the pilot reactor required a higher concentration of electron donor and took a longer time for the reactor to reach anoxic conditions. During electron donor weaning of the laboratory reactors it was possible to decrease the electron donor to the theoretical electron donor demand without decreasing the hexavalent chromium reduction potential; however, this balance is more difficult to achieve for the pilot reactor where factors on site can influence stoichiometry, e.g., blasting with ammonium nitrate, rainfall, etc. Once the electron donor concentration in the pilot reactor was decreased to below approximately double the theoretical electron donor demand, the hexavalent chromium reduction potential decreased. Research results presented in this paper provide the basis for a low-cost, and low-maintenance strategy for the biological treatment of hexavalent chromium-contaminated water.

\section{ACKNOWLEDGEMENT}

This study was conducted with financial support from the TIA/ UFS Metagenomics Platform and the THRIP programme (TP2010070800024) of the National Research Foundation. We 
would also like to acknowledge the DST/NRF for an Innovation Postdoctoral Fellowship grant.

\section{REFERENCES}

ACKERLEY DF, GONZALEZ CF, KEYHAN M, BLAKE R and MATIN A (2004) Mechanism of chromate reduction by the Escherichia coli protein, $\mathrm{Nfs}$ A, and the role of different chromate reductases in minimizing oxidative stress during chromate reduction. Environ. Microbiol. 6 851-860.

AMOOSEGAR MA, GHASEMI A, RAZAVI MR and NADDAF S (2007) Evaluation of hexavalent chromium reduction by chromate-resistant moderately halophile, Nesterenkonia sp. Strain MF2. Proc. Biochem. 42 1475-1479.

ARLAUSKAS A, BAKER RS, BONIN AM, TANDON RK, CRISP PT and ELLIS J (1985) Mutagenicity of metal ions in bacteria. Environ. Res. 36 379-388.

BARCELOUX DG (1999) Chromium. J. Toxicol. Clin. Toxicol. 37 173-194.

BLOTHE M, AKOB DM, KOSTKA JE, GOSCHEL K, DRAKE HL and KASEL K (2008) pH gradient-induced heterogeneity of Fe(III)reducing microorganisms in coal mining-associated lake sediments. Appl. Environ. Microbiol. 74 1019-1029.

BOTES E, JORDAN R, DeFLAUN MF, HOWELL J, BORCH R, LIEBENBERG FC and VAN HEERDEN E (2010) Bioremediation of hexavalent chromium contaminated water in fixed-film upflow reactors - a South African first. J. Biotechnol. 150 269-269.

CHEN W, LAEVENS S, LEE T, COENYE T, DE VOS P, MERGEAY M and VANDAMME P (2001) Ralstonia taiwanensis sp. nov., isolated from root nodules of Mimosa species and sputum of a cystic fibrosis patient. Int. J. Syst. Evol. Microbiol. 51 1729-1735.

COENYE T, FALSEN E, VANCANNEYT M, HOSTE B, GOVAN JRW, KERSTERS K and VANDAMME P (1999) Classification of Alcaligenes faecalis-like isolates from the environment and human clinical samples as Ralstonia gilardii sp. nov. Int. J. Syst. Bacteriol. 49 405-413.

DESAI C, JAIN K and MADAMWAR D (2008) Hexavalent chromate reductase activity in cytosolic of Pseudomonas sp. G1DM21 isolated from chrome(VI) contaminated industrial landfill. Proc. Biochem. 43 713-721.

DWAF (DEPARTMENT OF WATER AFFAIRS AND FORESTRY, SOUTH AFRICA) (1998) Minimum requirements for the handling, classification and disposal of hazardous waste. Waste Management Series ( $2^{\text {nd }}$ edn.). Department of Water Affairs and Forestry, Pretoria.

KANOJIA RK, JUNAID M and MURTHY RC (1998) Embryo and fetotoxicity of hexavalent chromium: a long-term study. Toxicol. Lett. 95 165-172.

KAWAICHI S, ITO N, KAMIKAWA R, SUGAWARA T, YOSHIDA T and SAKO Y (2013) Ardenticatena maritima gen. nov., sp. nov., a ferric iron-and nitrate reducing bacterium of the phylum Chloroflexi isolated from an iron-rich coastal hydrothermal field, and description of Ardenticatenia classis nov. Int. J. Syst. Evol. Microbiol. 63 2992-3002.

LOSI ME and FRANKENBERGER WT (1997) Reduction of selenium oxyanions by Enterobacter cloacae SLD1a-1: Isolation and growth of the bacterium and its expulsion of selenium particles. Appl. Environ. Microbiol. 63 3079-3084.

MACUR RE, JACKSON CR, BOTERO LM, McDERMOTT TR and INSKEEP WP (2004) Bacterial populations associated with the oxidation and reduction of arsenic in an unsaturated soil. Environ. Sci. Technol. 38 104-111.

MARSILI E, BEYENAL H, DI PALMA L, MERLI C, DOHNALKOVA A AMONETTE JE and LEWANDOWSKI Z (2007) Uranium immobilization by sulfate-reducing biofilms grown on hematite, dolomite, and calcite. Environ. Sci. Technol. 41 8349-8354.

MUYZER G, DE WAAL EC and UITTERLINDEN AG (1993) Profiling of complex microbial populations by denaturing gradient gel electrophoresis analysis of polymerase chain reaction-amplified genes coding for 16S rRNA. Appl. Environ. Microbiol. 59 695-700.

OPPERMAN DJ and VAN HEERDEN E (2007) Aerobic Cr(VI) reduction by Thermus scotoductus strain SA01. J. Appl. Microbiol. 103 1907-1913.

ORANDI S, LEWIS DM, ESLAMI A and MOHEBBI A (2012) A novel approach to exploit indigenous mining algal-microbes in a photo-rotating biological contactor for heavy metal removal from acid mine drainage. Edith Cowan University, Bunbury.

PARK H, KIM JS, KIM DK, CHOI Y and PAK D (2006) Nitrate-reducing bacterial community in a biofilm-electrode reactor. Enzyme Microb. Technol. 3 453-458.

PORTER KG and FEIG YS (1980) The use of DAPI for identifying and counting aquatic microflora. Limnol. Oceanogr. 25 943-948.

REGE MA, PETERSEN JN, JOHNSTONE DL, TURICK CE, YONGE DR and APEL WA (1997) Bacterial reduction of hexavalent chromium by Enterobacter cloacae strain $\mathrm{HO}$ grown on sucrose. Biotechnol. Lett. 19 691-694.

REYSENBACH AL, GIVER LJ, WICKHAM GS and PACE NR (1992) Differential amplification of rRNA genes by polymerase chain reaction. Appl. Environ. Microbiol. 58 3417-3418.

RIDLEY H, WATTS CA, RICHARDSON DJ and BUTLER CS (2006) Resolution of distinct membrane-bound enzymes from Enterobacter cloacae SLD1a-1 that are responsible for selective reduction of nitrate and selenite oxyanions. Appl. Environ. Microbiol. 72 5173-5180.

SARRET G, AVOSCAN L, CARRIERE M, COLLINS R, GEOFFROY N, CARROT F, COVES J and GOUGET B (2005) Chemical forms of selenium in the metal-resistant bacterium Ralstonia metallidurans CH34 exposed to selenite and selenite. Appl. Environ. Microbiol. 71 2331-2337.

SCHNEIDER A, GERBI V and REDOGLIA M (1987) A rapid HPLC method for separation and determination of major organic acids in grape must and wines. Am. J. Enol. Viticult. 38 151-155.

SANS (SOUTH AFRICAN NATIONAL STANDARD) (2011) South African National Standard 241-1: Drinking water ( $1^{\text {st }}$ edn.). South African Bureau of Standards, Pretoria. 1-15.

STUMM W and MORGAN JJ (1996) Oxidation and Reduction; Equilibria and Microbial Mediation. In: Schnoor JL and Zehnder A: Aquatic Chemistry - Chemical Equilibria and Rates in Natural Waters ( $3^{\text {rd }}$ edn.). John Wiley and Sons, New York. 425-515.

SZPYRKOWICZ L, JELSALL GH, KAUL SN and FAVERI MD (2001) Performance of electrochemical reactor for treatment of tannery wastewaters. Chem. Eng. Sci. 56 1579-1586.

THACKER U, PARIKH R, SHOUCHE Y and MADAMWAR D (2006) Hexavalent chromium reduction by Providencia sp. Proc. Biochem. 41 1332-1337.

URONE PF (1955) Stability of colorimetric reagent for chromium, s-diphenylcarbazide, in various solvents. Anal. Chem. 27 1354-1355.

VALLS M, ATRIAN S, DE LORENZO V and FERNANDEZ LA (2000) Engineering a mouse metallothionein on the cell surface of Ralstonia eutropha CH34 for immobilization of heavy metals in soil. Nat. Biotechnol. 18 661-665.

WANG PC, MORI T, KOMORI K, SASATSU M, TODA K and OHTAKE H (1989) Isolation and characterization of an Enterobacter cloacae strain that reduces hexavalent chromium under anaerobic conditions. Appl. Environ. Microbiol. 55 1665-1669.

WANG PC, MORI T, TODA K and OHTAKE H (1990) Membraneassociated chromate reductase activity from Enterobacter cloacae. J. Bacteriol. 172 1670-1672.

WARD NL, CHALLACOMBE JF, JANSSEN PH, JANSSEN PH, HENRISSAT B, COUTINHO PM, WU M, XIE G, HAFT DH, SAIT M, BADGER J, BARABOTE RD, BRADLEY B, BRETTIN TS, BRINKAC LM, BRUCE D, CREASY T, DAUGHERTY SC, DAVIDSEN TM, DEBOY RT, DETTER JC, DODSON RJ, DURKIN AS, GANAPATHY A, GWINN-GIGLIO M, HAN CS, KHOURI H, KISS H, KOTHARI SP, MADUPU R, NELSON KE, NELSON WC, PAULSEN I, PENN K, REN Q, ROSOVITZ MJ, SELENGUT JD, SHRIVASTAVA S, SULLIVAN SA, TAPAI R, THOMPSON LS, WATKINS KL, YANG Q, YU C, ZAFAR N, ZHOU L and KUSKE CR (2009) Three genomes from the Phylum Acidobacteria provide insight into the lifestyles of these microorganisms in soils. Appl. Environ. Microbiol. 75 (7) 2046-2056.

WATTS CA, RIDLEY H, CONDIE KL, LEAVER JT, RICHARDSON DJ and BUTLER CS (2003) Selenate reduction by Enterobacter cloacae SLD1a-1 is catalysed by a molybdenum-dependent membrane-bound enzyme that is distinct from the membrane-bound nitrate reductase. FEMS Microbiol. Lett. 228 273-279.

YEE N, MA J, DALIA A, BOONFUENG T and KOBAYASHI DY (2007) $\mathrm{Se}(\mathrm{VI})$ reduction and the precipitation of $\mathrm{Se}(0)$ by the facultative bacterium Enterobacter cloacae SLD1a-1 are regulated by FNR. Appl. Environ. Microbiol. 73 1914-1920. 